Vol. 24, No. 3, Juli 2021, hlm. 401-411

p-ISSN: 1410-9344; e-ISSN: 2549-5631

WARTA LPM

homepage: http://journals.ums.ac.id/index.php/warta

\title{
Pencegahan Covid-19 pada Anak Sekolah Dasar dengan Pembiasaan Tatanan Normal Baru
}

\author{
${ }^{1}$ Nur Lina, ${ }^{2}$ Fitriyani Yuliawati, ${ }^{2}$ Wiwi Widiastuti, ${ }^{2}$ Taufik Nurohman \\ ${ }^{1}$ Prodi Kesehatan Masyarakat, Fakultas Ilmu Kesehatan Universitas Siliwangi \\ ${ }^{2}$ Prodi Ilmu Politik, Fakultas Ilmu Sosial dan Ilmu Politik Universitas Siliwangi \\ email: ${ }^{1}$ nurlina@unsil.ac.id
}

\begin{tabular}{l}
\hline \multicolumn{1}{c}{ Article Info } \\
\hline Submitted:20 November 2020 \\
Revised: 18 February 2021 \\
Accepted: 27 April 2021 \\
Published: 20 July 2021
\end{tabular}

Keywords: Prevention, Covid-19, Elementary School

Kata kunci: Pencegahan, Covid-19, Sekolah Dasar

\begin{abstract}
Positive cases of Covid-19 in the City of Tasikmalaya until June 14, 2020, totaled 49 people. Tawang sub-district is a sub-district with the highest number of positive Covid-19 cases in Tasikmalaya City. The presence of positive sufferers of Covid-19, the presence of PDP, ODP, and OTG put children atrisk of contracting Covid-19. The purpose of this Health Scheme Community Service (PbM-SK) is the prevention of Covid-19 in children with the New Normal Order Habit. PbM-SK is carried out in collaboration with 2 (two) partners, namely SDN 1 Cikalang and SDN Cilolohan which are located in Tawang District. The problems faced by partners are the existence of positive cases of Covid-19 in the elementary school, the lack of means of preventing Covid-19 and the absence of socialization of the new normal order. Solutions to overcome the lack of means of preventing Covid-19 are carried out by providing hand washing facilities, masks and banners. The solution has not been socialized to the new normal order habituation, is done by doing face-to-face counseling with the lecture and discussion method with the target teacher. After counseling about Covid-19, there was an increase in the average pretest score of 5.39. Wilcoxon statistical test results obtained $P$ value 0.007, meaning that there is a significant difference in the average value of knowledge before and after counseling. This increase shows that teachers' knowledge in efforts to prevent Covid-19 has increased in a positive direction, meaning that partners perceive to be better at preventing Covid-19 in children. It is recommended that teachers as cadres of school action movements continue activities by educating their students in preventing Covid-19.
\end{abstract}

Abstrak
Kasus positif Covid-19 Kota Tasikmalaya sampai dengan 14 Juni
2020 berjumlah 49 orang. Kecamatan Tawang adalah kecamatan
dengan jumlah kasus positif Covid-19 tertinggi di Kota Tasikmalaya.
Keberadaan penderita positif Covid-19, adanya PDP, ODP, dan OTG
menyebabkan anak-anak berisiko tertular Covid-19. Tujuan dari


Pengabdian Masyarakat Skema Kesehatan (PbM-SK) ini adalah pencegahan Covid-19 pada anak dengan Pembiasaan Tatanan Normal Baru. PbM-SK dilakukan bekerjasama dengan 2 (dua) mitra yaitu SDN 1 Cikalang dan SDN Cilolohan yang terletak di Kecamatan Tawang. Permasalahan yang dihadapi oleh mitra yaitu adanya kasus positif Covid-19 di SD tersebut, kurangnya sarana pencegahan Covid-19 dan belum adanya sosialisasi tatanan normal baru. Solusi untuk mengatasi kurangnya sarana pencegahan Covid-19 dilakukan dengan memberikan fasilitas cuci tangan, masker, dan banner. Solusi belum tersosialisasi pembiasaan tatanan normal baru, dilakukan dengan penyuluhan yang dilakukan secara tatap muka dengan metode ceramah dan diskusi dengan sasaran guru. Setelah dilakukan penyuluhan tentang Covid-19, terjadi peningkatan rata rata nilai pretest sebesar 5,39. Hasil uji statistik wilcoxon didapatkan $P$ value 0,007 , artinya terdapat perbedaan nilai rata rata pengetahuan yang signifikan sebelum dan sesudah penyuluhan. Peningkatan ini menunjukkan bahwa pengetahuan guru dalam upaya pencegahan Covid-19 meningkat ke arah positif, artinya guru berpersepsi ke arah lebih baik dalam pencegahan Covid-19 pada anak. Disarankan agar guru sebagai kader gerak aksi sekolah melanjutkan kegiatan dengan mengedukasi siswanya dalam mencegah Covid-19.

\section{PENDAHULUAN}

Coronavirus Disease 2019 (Covid-19) adalah penyakit jenis baru yang belum pernah diidentifikasi sebelumnya pada manusia. koronavirus adalah salah satu patogen utama yang terutama menargetkan sistem pernapasan manusia. Gejala Covid-19 muncul setelah masa inkubasi sekitar 5 hari. Gejala yang paling umum pada awal penyakit Covid-19 adalah demam, batuk, dan kelelahan, sementara gejala lainnya termasuk produksi dahak, sakit kepala, hemoptysis (batuk darah), diare, dyspnea (sesak nafas), dan limfopenia. Saat ini, tidak ada obat antivirus khusus atau vaksin terhadap infeksi Covid-19 untuk terapi potensial pada manusia (H.A. Rothan, 2020). Virus penyebab Covid-19 adalah Sars-CoV-2, masa inkubasi rata-rata 5-6 hari dengan masa inkubasi terpanjang 14 hari. Kasus Covid-19 yang berat dapat menyebabkan pneumonia, sindrom pernapasan akut, gagal ginjal, dan bahkan kematian. Tanda-tanda dan gejala klinis yang dilaporkan pada sebagian besar kasus adalah demam dengan beberapa kasus mengalami kesulitan bernapas, dan hasil rontgen menunjukkan infiltrat pneumonia luas di kedua paru. Pada tanggal 30 Januari 2020, WHO menetapkan Covid-19 sebagai Public
Health Emergency of International Concern (PHEIC)/ Kedaruratan Kesehatan Masyarakat yang Meresahkan Dunia (KKMMD).

Pada tanggal 2 Maret 2020 Indonesia telah melaporkan 2 kasus konfirmasi Covid-19. Pada tanggal 11 Maret 2020, WHO menetapkan Covid-19 sebagai pandemi (Kemenkes, 2020). Beberapa orang yang terinfeksi Covid-19 tidak melaporkan gejala sama sekali. Transmisi terjadi ketika berada dalam kontak dekat (dalam 1 meter) dengan orang yang terinfeksi misalnya, melalui batuk, bersin atau kontak pribadi yang sangat dekat yang mengakibatkan inokulasi portal entri seperti mulut, hidung, atau konjungtiva. Penularan juga dapat terjadi melalui fomites/muntahan di sekitar orang yang terinfeksi. Dalam konteks pandemi Covid-19, WHO memberikan anjuran bahwa semua orang harus menghindari kerumunan/kelompok orang dan ruang ramai, menjaga jarak fisik minimal 1 meter (3.3 kaki) dari orang lain, terutama dari mereka yang bergejala penyakit saluran pernapasan (misalnya batuk dan bersin), sering cuci tangan, menggunakan handrub berbasis alkohol jika tangan tidak tampak kotor atau sabun dan air; menutupi hidung dan mulut dengan siku tertekuk atau kertas tisu saat batuk 
atau bersin, membuang tisu segera setelah digunakan, dan menjaga kebersihan tangan; tidak menyentuh mulut, hidung, dan mata. Penggunaan masker adalah bagian dari langkahlangkah pencegahan dan kontrol yang dapat membatasi penyebaran Covid-19. Masker dapat digunakan untuk perlindungan orang sehat (dipakai untuk melindungi diri sendiri ketika kontak dengan orang yang terinfeksi individu) atau untuk kontrol sumber (dikenakan oleh yang terinfeksi individu untuk mencegah penularan selanjutnya) (WHO, 2020). Covid-19 menyerang siapa saja, umur berapa saja, termasuk anakanak.

Secara global, pada pukul 9:13 pagi CEST, 14 Juni 2020, ada 7.633.886 kasus Covid-19 yang dikonfirmasi, termasuk 426.317 kematian dilaporkan ke WHO (WHO, 2020). Jumlah kasus Covid-19 di Indonesia berdasarkan data dari Gugus Tugas Percepatan Penanganan Covid-19 (Gugus Tugas Nasional) adalah positif 37.420 orang, sembuh 13.776 orang, dan meninggal 2.091 orang (Kemenkes, 2020). Jumlah PDP Covid-19 pada anak dan data kasus Covid-19 pada anak hingga Selasa (18/5/2020) PDP sebanyak 3.324 kasus, 129 anak berstatus PDP meninggal dunia, 584 kasus anak terkonfirmasi positif Covid-19, dan 14 anak meninggal akibat Covid-19. Anak anak rentan tertular Covid-19 dari orang dewasa yang dinyatakan positif terinfeksi virus corona apabila daya tahan tubuh anak rendah. Tanda dan gejala Covid-19 pada anak sulit dibedakan dari penyakit saluran pernafasan akibat penyebab lainnya (IDAI, 2020).

Jumlah kasus positif Covid-19 Kota Tasikmalaya sampai dengan 14 Juni 2020 berjumlah 49 orang. Kecamatan Tawang Kota Tasikmalaya adalah kecamatan dengan jumlah kasus positif Covid-19 tertinggi di Kota Tasikmalaya. Berdasarkan hasil pemeriksaan PCR di Kecamatan Tawang didapatkan angka jumlah kasus positif PCR 11 orang, positif RDT 2 orang, PDP 10 orang, ODP 71 orang, dan OTG 172 orang (Diskominfo, 2020). Kasus positif Covid-19 pada anak juga didapatkan di Kecamatan Tawang kota Tasikmalaya yaitu pada murid SDN 1 Cikalang. Adanya kasus positif Covid-19 menyebabkan anak-anak, khususnya di SDN 1 Cikalang dan SDN Cilolohan yang letaknya berdekatan menjadi rentan untuk terjadi penularan.
Langkah-langkah pribadi dan masyarakat harus diadopsi untuk menekan transmisi Covid-19. Penggunaan masker di masyarakat, kepatuhan untuk menjaga kebersihan tangan, menjaga jarak fisik, dan pencegahan infeksi lainnya. Tindakan pengendalian sangat penting untuk mencegah penularan Covid-19 dari manusia ke manusia. Informasi dan panduan tentang penggunaan masker sangat penting untuk diberikan. Tindakan pencegahan adalah strategi untuk membatasi penyebaran kasus (Marco, 2020).

Permasalahan yang dihadapi oleh mitra yaitu SDN 1 Cikalang dan SDN Cilolohan adalah adanya adanya kasus positif Covid-19 pada murid SDN 1 Cikalang. Kurangnya fasilitas cuci tangan, tidak tersedia hand sanitizer, masker, serta belum tersosialisasinya pembiasaan tatanan normal di SDN 1 Cikalang dan SDN Cilolohan menyebabkan seluruh murid dan guru rentan untuk terpapar virus Corona. Solusi yang ditawarkan penulis adalah melakukan pengabdian masyarakat skema kesehatan untuk pencegahan Covid-19 pada anak dengan pembiasaan tatanan normal baru melalui Komunikasi, Informasi dan Edukasi (KIE) tentang pembiasaan tatanan normal baru, memberian sarana cuci tangan, sabun serta hand sanitizer, dan masker dewasa dan anak-anak. Membentuk satuan kader gerak aksi sekolah pandemi yang beranggotakan guru yang berperan sebagai kader kesehatan dan bertugas menyampaikan informasi tentang pencegahan Covid-19 pada anak dengan pembiasaan tatanan normal baru.

Guru memainkan peran penting sebagai kader gerak aksi sekolah pandemi untuk mendukung program pemerintah, dalam pemulihan kehidupan masyarakat (new normal) dalam membantu siswa memahami penyakit Covid-19 dan mengatasi kecemasan. Karena itu, guru harus aktif mencari informasi yang benar dan membantu siswa agar tidak terperangkap hoaks atau informasi yang salah. Guru harus mencontohkan perilaku-perilaku yang melindungi diri dan orang lain. Guru juga diharapkan dapat membantu mencuci tangan menggunakan sabun dan air mengalir yang benar. Guru perlu mengenalkan virus corona pada siswa misalnya dengan mengajak siswa membuat poster, menulis puisi atau esai tentang cara melindungi diri dan orang lain, 
mempraktikkan cara menutup hidung dan mulut saat bersin atau batuk, cara berjabat tangan gaya baru yang aman, dan membersihkan ruangan dan lingkungan sekolah secara rutin (minimal 1 kali sehari) dengan disinfektan, khususnya gagang pintu, saklar lampu, komputer, meja, keyboard, dan fasilitas lain yang sering terpegang oleh tangan. Guru juga memfasilitasi pembelajaran jarak jauh secara daring, luring, maupun kombinasi keduanya sesuai dengan kondisi dan ketersediaan sarana pembelajaran. Muatan penugasan adalah pendidikan kecakapan hidup, antara lain mengenai pandemi Covid-19. Selain itu, perlu dipastikan adanya konten rekreasional (Kemendikbud, 2020).

Protokol kesehatan pandemi Covid-19 dalam memasuki tatanan normal baru bertujuan untuk terwujudnya tatanan normal baru (New Normal) masyarakat Indonesia yang cerdas, sehat, dan tangguh serta mandiri dalam menghadapi pandemi Covid-19. Sebagai bagian dari warga negara Indonesia, tim pengusul peduli dan termotivasi untuk membantu pemerintah dalam upaya pencegahan Covid-19 pada anak. Salah satu langkah dasar pengendalian ialah dengan pembiasaan tatanan normal baru, yakni menggunakan masker, cuci tangan pakai sabun, dan physical distancing dengan melaksanakan kegiatan Pengabdian Masyarakat Skema Kesehatan (PbM-SK) dengan tema "Pencegahan Covid-19 pada Anak dengan Pembiasaan Tatanan Normal Baru" yang merupakan Komunikasi, Informasi, dan Edukasi (KIE) untuk mencegah terjadinya Covid-19 pada anak-anak yang sangat berguna agar bisa mendorong anak-anak membiasakan tatanan normal baru sehingga mencegah terjadinya Covid-19. Pencegahan Penyakit Covid-19 pada anak-anak dengan pembiasaan tatanan normal baru merupakan bagian dari manajemen pencegahan terhadap terjadinya penyakit menular khususnya Covid-19.

Pelaksanaan kegiatan PbM-SK dilakukan bekerjasama dengan 2 mitra yaitu SDN 1 Cikalang dan SDN Cilolohan yaitu Sekolah Dasar yang terletak di Kecamatan Tawang yang merupakan kecamatan dengan jumlah kasus positif Covid-19 paling tinggi di wilayah Kota Tasikmalaya. Permasalahan yang dihadapi oleh mitra yaitu SDN 1 Cikalang dan SDN Cilolohan adalah adanya adanya kasus positif Covid-19 pada murid SDN 1
Cikalang, kurangnya fasilitas cuci tangan, tidak tersedia hand sanitizer, masker, serta belum tersosialisasinya pembiasaan tatanan normal di SDN 1 Cikalang dan SDN Cilolohan sehingga menyebabkan seluruh murid dan guru rentan untuk terpapar virus Corona. Hasil pertemuan dan diskusi dengan mitra, disepakati bahwa upaya pemecahan masalah dilakukan dengan; 1) Memberian fasilitas cuci tangan, sabun, dan hand sanitizer di SDN 1 Cikalang dan SDN Cilolohan, 2) Mengedukasi siswa dalam aksi gerakan hidup bersih sehat mengendalikan pandemi Covid-19 dengan rajin cuci tangan menggunakan sabun, memakai masker, dan menjaga jarak fisik minimal 1 meter melalui media (spanduk, banner), dan 3) Membentuk satuan kader gerak aksi sekolah pandemi yang beranggotakan guru yang sudah diberikan materi tentang pencegahan Covid-19 pada anak untuk mendukung program pemerintah, dalam pemulihan kehidupan masyarakat (new normal).

\section{METODE}

Upaya yang dilakukan tim pengusul agar mitra memiliki kesadaran terhadap pencegahan Covid-19 sehingga mau melakukan dasar pengendalian dengan pembiasaan tatanan normal baru, yakni menggunakan masker, cuci tangan pakai sabun, dan physical distancing. Prinsip pembelajaran yang menekankan bahwa transfer Ipteks dimulai dengan transfer knowledge, perubahan persepsi atau sikap, dan mengadopsi melalui praktik.

Transfer Ipteks tersebut meliputi tahapan kegiatan; (1) Transfer knowledge yaitu memberikan informasi dengan mendengarkan, menyimak, dan menanggapi. Metode yang digunakan pada tahap ini adalah metode ceramah dan diskusi mengenai pencegahan Covid-19 pada anak dengan tatanan normal baru dangan alat bantu slide Power Point (PPT) yang dilakukan selama kurang lebih 1 jam dengan sasaran guru; kemudian dibentuk kader gerak sekolah pandemi yang berganggotakan guru yang sudah diberi penyuluhan. Guru kemudian bertugas menyampaikan materi yang sudah diberikan kepada murid-murid. (2) Perubahan persepsi, mitra menerima informasi melalui mengamati, demonstrasi, dan penggunaan media atau alat peraga berupa poster, spanduk, 
dan banner. (3) Adopsi, mitra menerima informasi dengan berlatih dan menerapkan. Metode yang dilakukan pada tahap ini adalah pelatihan tahapan cuci tangan pakai sabun yang diperagakan oleh tim pengabdian masyarakat kepada guru, juga diberikan media edukasi berupa poster langkah cuci tangan.

Pengabdian Masyarakat Skema Kesehatan (PbM-SK) ini dilakukan di SDN 1 Cikalang dan SDN Cilolohan. SDN 1 Cikalang berlokasi di Jalan Siliwangi No. 111 dan SDN Cilolohan berlokasi di Jl. Siliwangi No. 66 Kota Tasikmalaya. SDN 1 Cikalang terletak $1,5 \mathrm{~km}$ dari Universitas Siliwangi sedangkan SDN Cilolohan terletak 1 km dari Universitas Siliwangi. SDN 1 Cikalang dan SDN Cilolohan dipilih karena merupakan salah satu SD yang terletak di Desa Kahuripan, Kecamatan Tawang dengan jumlah kasus positif Covid-19 tertinggi di wilayah Kota Tasikmalaya. Guru dipilih menjadi sasaran karena guru memainkan peran penting sebagai kader gerak aksi sekolah pandemi untuk mendukung program pemerintah dalam pemulihan kehidupan masyarakat (new normal) dalam membantu siswa memahami penyakit Covid-19 sedangkan siswa SD dipilih karena anak anak lebih rentan tertular Covid-19 sehingga anak-anak diharapkan dapat melakukan upaya pencegahan Covid-19 dengan pembiasaan tatanan normal baru, yakni menggunakan masker, cuci tangan pakai sabun, dan physical distancing. Kegiatan penyuluhan mengenai pencegahan Covid-19 pada anak dilakukan dengan memberikan pretest untuk mengukur pengetahuan peserta sebelum penyuluhan kemudian dilakukan pemberian materi selama 1 jam dilanjutkan dengan diskusi dan demo tahapan cuci tangan. Materi penyuluhan tentang pencegahan Covid-19 pada anak disampaikan oleh ketua tim peneliti yang berlatar belakang pendidikan S2 kesehatan masyarakat, mengajar mata kuliah epidemiologi penyakit menular salah satunya penyakit yang ditularkan melalui udara (Air Borne Disease). Anggota tim pengusul berpendidikan S2 di bidang Ilmu Sosial Politik Anggota pengusul juga aktif melakukan kegiatan PPM yang bertugas untuk mempersiapkan sarana cuci tangan, masker, hand sanitizer, sabun, spanduk, dan banner mengenai pencegahan Covid-19 pada anak. Evaluasi pengetahuan setelah penyuluhan dilakukan dengan memberikan postest.

Tujuan setiap tahapan adalah sebagai berikut; (1) Identifikasi kebutuhan mitra terhadap tatanan normal baru, yakni kebutuhan sarana cuci tangan, sabun, hand sanitizer, dan masker. (2) Sosialisasi bertujuan untuk memberikan pengetahuan dan pemahaman kepada mitra mengenai pencegahan penularan Covid-19 pada anak-anak, dilakukan dengan penyuluhan secara tatap muka dengan protokol kesehatan yang bertujuan agar mitra bersikap atau berpersepsi baik sehingga mau menjadi kader gerak aksi sekolah pandemi.

Test pengetahuan (pretest) digunakan sebagai alat untuk mengukur pengetahuan mitra mengenai pencegahan Covid-19 pada anak anak sebelum penyuluhan yang terdiri dari 10 pertanyaan dibagikan melalui link Google Form, selanjutnya dilakukan penyuluhan mengenai pencegahan Covid-19 pada anak yang bertujuan untuk memberikan pengetahuan dan pemahaman kepada mitra mengenai pencegahan penularan Covid-19 pada anak anak, penyuluhan dilakukan secara tatap muka dengan protokol kesehatan. Selanjutnya diberikan postest merupakan pemberian pertanyaan berupa soal latihan yang digunakan pada saat pretest dengan susunan soal yang diacak, hal ini bertujuan untuk mengetahui apakah ada peningkatan pengetahuan mitra sebelum dan sesudah penyuluhan mengenai pencegahan penularan Covid-19 pada anak. Uji statistik Wilcoxon digunakan untuk mengetahui berbedaan nilai rata sebelum perlakuan (pretest) dan sesudah perlakuan (postest). (3) demo langkah cuci tangan dilakukan untuk memastikan mitra (guru) mampu menjelaskan langkah cuci tangan.

Melalui tahapan-tahapan tersebut diharapkan proses transfer Ipteks yang diberikan bisa sustainable, menjadi kebiasaan yang dilakukan oleh mitra. SDN 1 Cikalang dan SDN Cilolohan dapat menjadi mitra sasaran bagi para dosen untuk melakukan kegiatan pengabdian pada masyarakat dalam bentuk pemanfaatan hasil penelitian di bidang kesehatan, penerapan teknologi tepat guna yang dilakukan oleh para dosen, yang dapat langsung dimanfaatkan dalam upaya-upaya mencegah penyebaran Covid-19. berikut:

Langkah-langkah digambarkan sebagai 


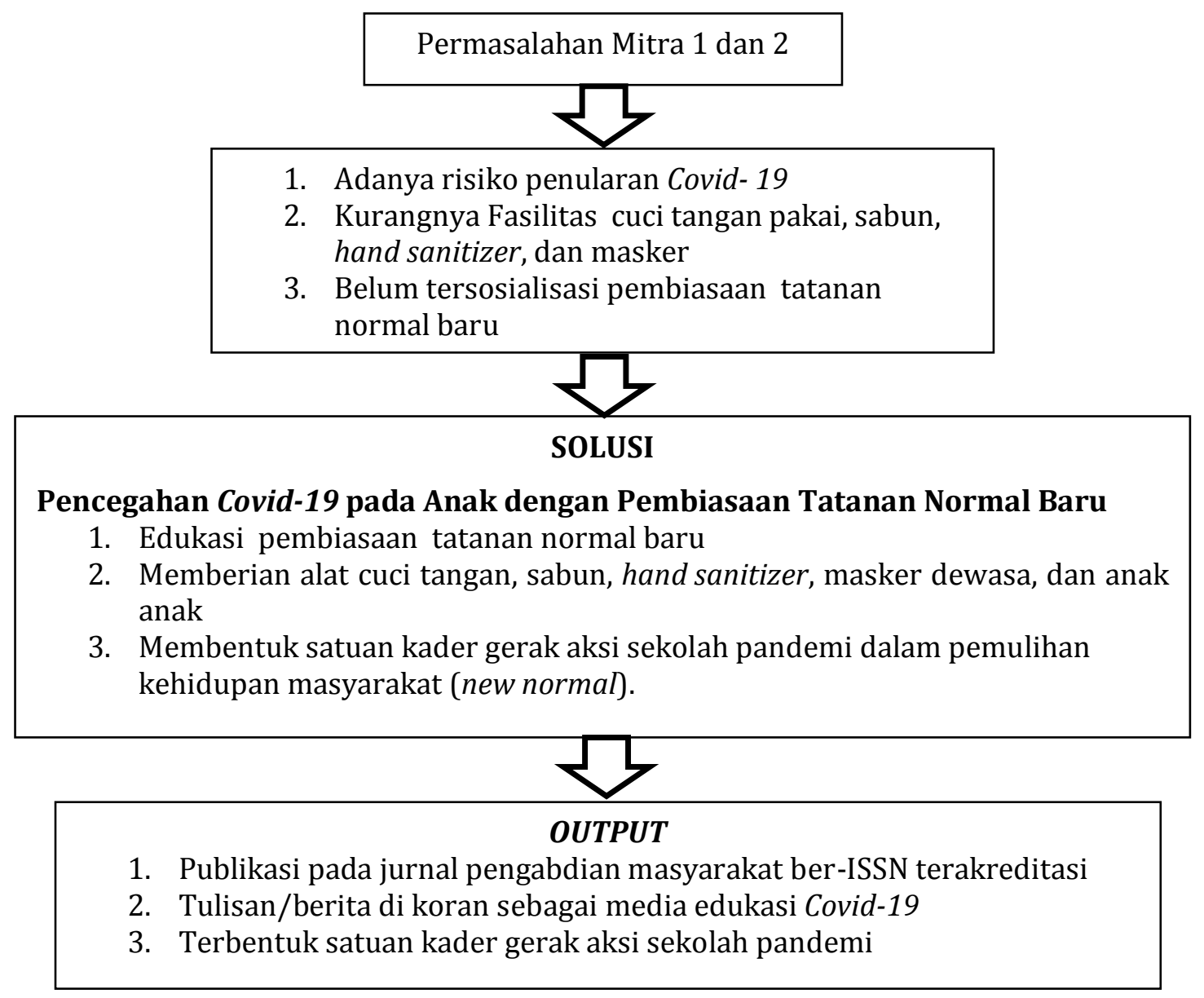

\section{HASIL DAN PEMBAHASAN}

Kegiatan PbM-SK dimulai dengan melaksanakan pembahasan rencana kegiatan pengabdian masyarakat yang dihadiri kepala sekolah SDN 1 Cikalang dan SDN Cilolohan. Hasil dari kegiatan ini adalah adanya kesepakatan waktu pelaksanaan pengabdian masyarakat SDN 1 Cikalang pada 24 September 2020 kemudian pengabdian masyarakat SDN Cilolohan tanggal 29 September 2020. Selanjutnya dilakukan kegiatan pengabdian masyarakat PbM-SK yang meliputi:

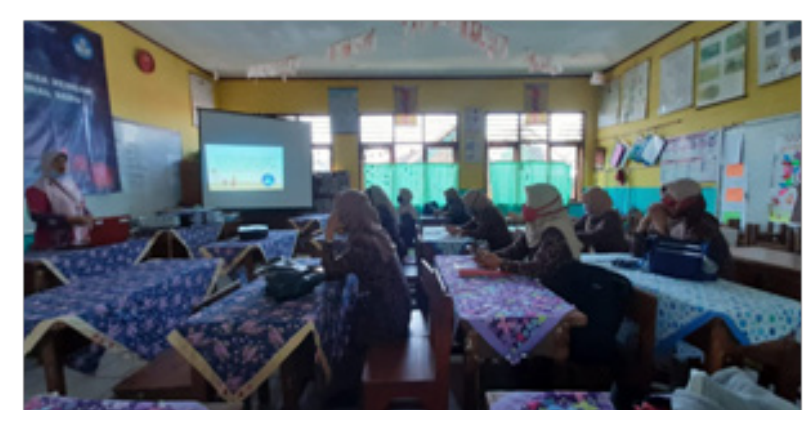

Gambar 1. KIE Mengenai Pencegahan Covid-19 pada Anak di SDN 1 Cikalang

\section{a. Komunikasi, Informasi, dan Edukasi (KIE) mengenai Covid-19:}

KIE dilakukan melalui penyuluhan dengan materi tentang Covid-19. Penyuluhan tentang Covid-19 dilakukan selama satu jam dimulai jam 10 pagi sampai dengan jam 11 diawali dengan pemberian pretest yang berisi 10 soal kemudian diberikan penyuluhan. Materi penyuluhan yang diberikan adalah upaya pencegahan terjadinya penularan Covid-19 pada anak. Setelah selesai penyuluhan diberikan postest.

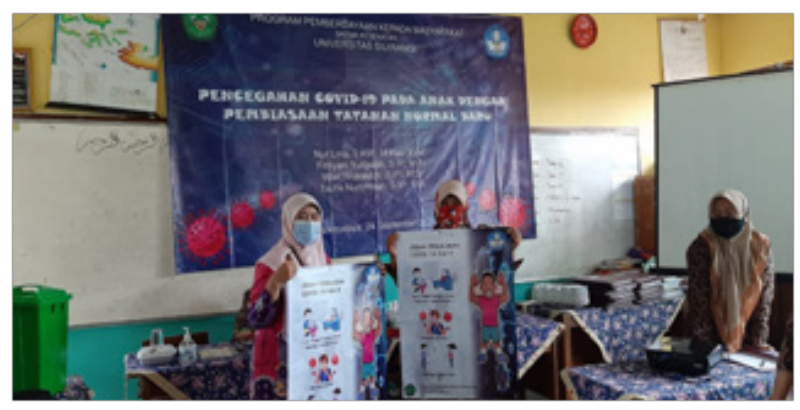

Gambar 2. Penyerahan Media Promosi Pencegahan Covid-19 di SDN Cilolohan 
KIE tentang Covid-19 di SDN 1 Cikalang dilakukan pada 24 September 2020 dilakukan di ruang kelas SDN 1 Cikalang yang dihadiri oleh Kepala Sekolah SDN 1 Cikalang dan 8 orang guru SDN 1 Cikalang. Jumlah peserta KIE dari SDN 1 Cikalang adalah 9 orang. KIE tentang Covid-19 di SDN Cilolohan dilakukan pada 29 September 2020 di ruang kelas SDN Cilolohan pada tanggal 29 September 2020 yang dihadiri oleh Kepala Sekolah SDN 1 Cikalang dan 16 orang guru SDN 1 Cikalang, jumlah peserta KIE dari SDN Cilolohan adalah 17 orang. Jumlah seluruh peserta KIE di SDN1 Cikalang dan SDN Cilolohan berjumlah 26 orang.

Materi yang diberikan dalam KIE Pencegahan Covid-19 pada anak antara lain hal-hal yang perlu lakukan untuk mencegah Covid-19 yaitu cuci tangan pakai sabun dengan menggunakan air mengalir 20 detik. Cuci tangan pakai sabun untuk mencegah Covid-19 saat tiba di rumah, setelah menggunakan toilet sekolah. Apabila sabun dan air mengalir tidak tersedia maka dapat menggunakan cairan pembersih tangan (minimal 60\% alkohol). Saat batuk atau bersin, tutup mulut dan hidung dengan siku terlipat. Menghindari kerumunan, jaga jarak minimal lebih dari $1 \mathrm{M}$. Bagian tubuh yang tidak boleh disentuh sebelum cuci tangan dengan sabun yaitu mata, hidung dan mulut. Hal hal yang harus dihindari untuk mencegah penularan Covid-19 yaitu bersalaman. Apabila guru atau siswa sakit istirahat di rumah. Membersihkan ruangan dan lingkungan sekolah setiap hari. Benda-benda yang harus di disinfektan untuk mencegah Covid-19 yaitu gagang pintu, saklar lampu, dan meja semua fasilitas sekolah yang sering terpegang oleh tangan.

Selain itu untuk meningkatkan kekebalan tubuh, maka anak-anak juga dianjurkan makan sayur dan buah yang dapat memetik dari pekarangan, atau kebun sendiri. Pangan lokal sesuai dengan kebiasaan dan sosial budaya setempat, tanpa perlu biaya yang mahal namun memiliki kandungan gizi yang tinggi untuk meningkatkan daya tahan tubuh sehingga dan mencegah penyakit (Hidayanti, 2019)

Hasil pengabdian masyarakat skema kesehatan (PMB-SK) ini adalah mitra mendapatkan informasi dan menyimak materi yang disampaikan terbukti dengan terjadinya peningkatan nilai rata rata pretest setelah dilakukan KIE tentang Covid-19, dari 93.46 menjadi 98.85. Peningkatan nilai rata rata pretest sebesar 5,39. Peningkatan ini menunjukkan bahwa pengetahuan mitra meningkat ke arah positif, artinya mitra berpersepsi ke arah lebih baik dalam pencegahan Covid-19 pada anak dengan pembiasaan tatanan normal baru.

Hasil uji normalitas Kolmogorof smirnov menunjukkan nilai $\mathrm{p}$ value hasil pretest 0.022 artinya data pretest berdistribusi tidak normal dan nilai postest mempunyai p value 0.000 artinya data postest berdistribusi tidak normal sehingga uji statistik yang digunakan untuk mengetahui perbedaan nilai rata-rata pretest dan postest adalah uji statistik wilcoxon. Hasil uji statistik wilcoxon didapatkan $P$ value 0,007 , artinya terdapat perbedaan nilai rata-rata pengetahuan yang signifikan sebelum dan sesudah KIE tentang pencegahan Covid-19 pada anak.

Mitra juga antusias menggunakan media yang diberikan dan semua meminta materi yang disampaikan. Melalui kegiatan KIE tentang Covid-19 yang diberikan diharapkan proses transfer Ipteks yang diberikan bisa sustainable, menjadi kebiasaan yang dilakukan oleh mitra dan mitra dapat membagikan kemampuan yang dimiliki mitra dapat mengenalkan virus corona dan mengetahui bahaya Covid-19 dengan mengajak siswa membuat poster, menulis puisi atau esai tentang cara melindungi diri dan orang lain, mempraktikkan cara menutup hidung dan mulut saat bersin atau batuk, dan cara berjabat tangan gaya baru yang aman. Membersihkan ruangan dan lingkungan sekolah secara rutin (minimal 1 kali sehari) dengan disinfektan, khususnya gagang pintu, saklar lampu, komputer, meja, keyboard, dan fasilitas lain yang sering terpegang oleh tangan. Guru juga memfasilitasi pembelajaran jarak jauh secara daring, luring, maupun kombinasi keduanya sesuai dengan kondisi dan ketersediaan sarana pembelajaran. Muatan penugasan adalah pendidikan kecakapan hidup, antara lain mengenai pandemi Covid-19.

\section{b. Terbentuk kader gerak aksi sekolah pandemi}

Adanya penularan Covid-19 di Kota Tasikmalaya khususnya di SDN 1 Cikalang di mana ada 1 orang siswa yang positif Covid-19 
harus dicegah dengan pembiasaan tatanan normal baru, yakni menggunakan masker, cuci tangan pakai sabun, dan physical distancing. Tim Pengabdian Masyarakat Skema Kesehatan (Pbm-Sk) ini berhasil membentuk satuan kader gerak aksi sekolah pandemi yang beranggotakan guru yang sudah mengikuti penyuluhan tentang pencegahan Covid-19 pada anak untuk mendukung program pemerintah, dalam pemulihan kehidupan masyarakat (new normal).

Tim PPM memberikan pengetahuan dan pemahaman kepada kader gerak aksi sekolah pandemi mengenai risiko penularan Covid-19 terutama pada anak anak, dilakukan dengan KIE yang bertujuan agar mitra bersikap atau berpersepsi baik sehingga mau menjadi kader gerak aksi sekolah pandemi yang aktif mendukung program pemerintah, dalam pemulihan kehidupan masyarakat (new normal).

Transfer Ipteks yang diberikan pada kegiatan KIE tentang Covid-19 telah diberikan kepada guru selaku kader gerak aksi sekolah pandemi meliputi tahapan kegiatan; (1) Transfer knowledge yaitu memberikan informasi tentang Covid-19, guru mendengarkan, menyimak, dan menanggapi. Metode yang digunakan pada tahap ini adalah menunjukkan bukti langsung risiko penularan Covid-19 karena adanya kasus positif Covid-19 yang terjadi di Kecamtan Tawang khususnya pada salah satu siswa SDN 1 Cikalang. Adanya kasus positif dapat menjadi sumber penularan Covid-19 pada anak anak SD 1 Cikalang; (2) Perubahan persepsi, mitra menerima informasi khususnya mengenai pencegahan Covid-19 salah satunya menghindari bersalaman, dan menjaga jarak walaupun sudah memakai masker karena masker yang digunakan tidak dapat melindungi $100 \%$ terhadap

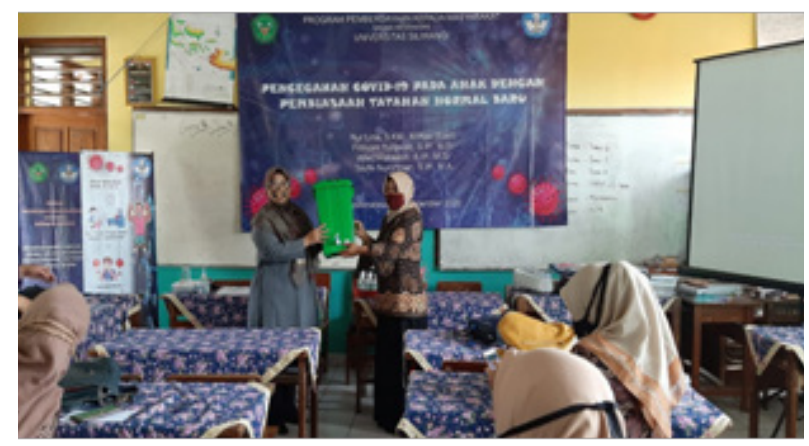

Gambar 3. Penyerahan Tempat Cuci Tangan Secara Simbolis di SDN1 Cikalang penularan Covid-19. Kegiatan yang dilakukan salah satunya demonstrasi, dan penggunaan media atau alat peraga. Metode yang digunakan pada tahap ini adalah penyuluhan (3) Adopsi: mitra menerima informasi dengan menjelaskan kembali cara pencegahan Covid-19 pada anak pada saat diskusi.

Output dari kegiatan ini adalah terbentuk kader gerak aksi sekolah pandemi yang beranggotakan guru yang sudah mengikuti penyuluhan tentang pencegahan Covid-19 pada anak. Melalui kegiatan pemberdayaan bertujuan agar guru sebagai kader gerak aksi sekolah pandemi mau melanjutkan kegiatan pengabdian masyarakat IbBM yaitu mengedukasi siswa dalam aksi gerakan hidup bersih sehat mengendalikan pandemi Covid-19 dengan rajin cuci tangan menggunakan sabun, memakai masker dan menjaga jarak fisik minimal 1 meter melalui media (spanduk, banner) yang diberikan.

\section{c. Pemberian sarana cuci tangan, sabun, hand sanitizer dan masker}

Faktor pembawa virus Covid-19 adalah manusia yang terinfeksi virus Covid-19. Virus akan tumbuh menjadi banyak di sepanjang saluran pernapasan mulai dari rongga hidung, mulut, sampai paru-paru. Virus akan keluar pada saat orang berbicara, bersin, dan batuk, menyebar bisa sampai radius 1 meter lebih dari dan menempel di benda-benda sekitar. Penularan Covid-19 karena memegang benda sekitar yang tercemar virus tersebut tidak bisa dihindarkan. Rajin cuci tangan dengan memakai sabun efektif membunuh virus covid-19. Covid-19 memiliki tubuh terbungkus oleh dinding dari struktur kimia lemah yang sangat mudah hancur apabila terkena sabun itu sebabnya harus cuci

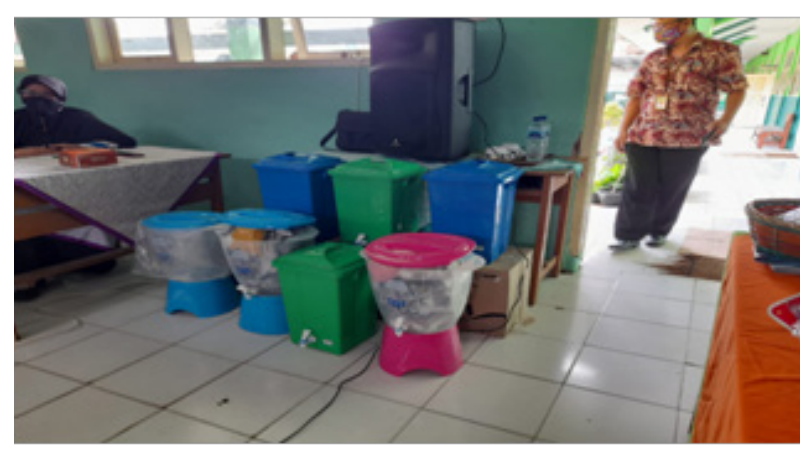

Gambar 4. Penyerahan Tempat Cuci Tangan di SDN Cilolohan 
tangan pakai sabun. Cuci tangan pakai sabun harus diiringi dengan jaga jarak fisik dengan orang lain lebih dari 1 meter. Jarak kurang dari 1 meter memungkinkan penularan menjadi lebih besar. Kita tidak pernah tahu siapa yang berada di luar rumah yang mengidap dan membawa virus Covid-19, sehingga penting untuk menjaga jarak. Selain cuci tangan memakai sabun, hal lain yang juga dianjurkan adalah menggunakan cairan pembunuh kuman dan virus seperti hand sanitizer. Akan tetapi cairan hand sanitizer bisa digunakan apabila tidak ada pilihan untuk mencuci tangan dengan sabun dan air mengalir (https://sehatnegeriku.kemkes.go.id/)

Kurangnya anggaran DIPA khusus untuk penanganan Covid-19 dirasakan oleh SDN 1 Cikalang dan SDN Cilolohan karena Pandemi Covid-19 terjadi dengan cepat. Kedua SD tersebut tidak menganggarkan dana khusus untuk pencegahan Covid-19 di sekolah, sedangkan fasilitas cuci tangan yang ada sangat terbatas terutama tempat cuci tangan portable yang dapat diletakkan di pintu masuk, sehingga setiap orang yang masuk ke lingkungan SD tersebut dapat cuci tangan terlebih dahalu. Persediaan sabun juga terbatas dalam anggaran 2020 serta tidak menganggarkan pembelian hand sanitizer.

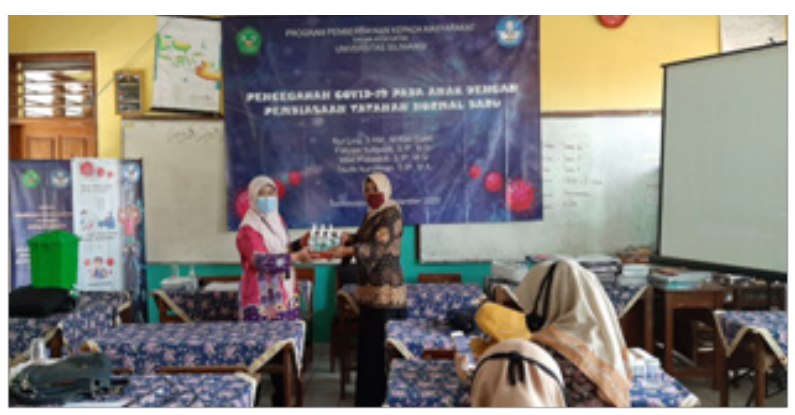

Gambar 5. Penyerahan Hand Sanitizer Secara Simbolis di SDN 1 Cikalang

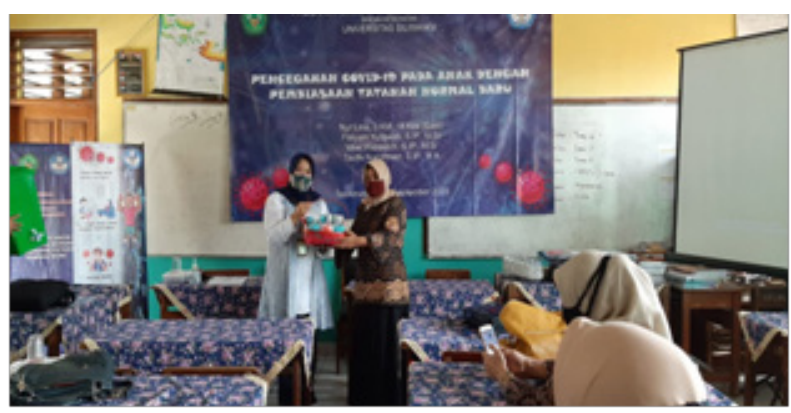

Gambar 7. Penyerahan Sabun Cuci Tangan Secara Simbolis di SDN 1 Cikalang
Solusi yang diberikan oleh Tim PPM adalah memberikan fasilitas cuci tangan yaitu tempat cuci tangan portable, sabun, dan hand sanitizer.

Kader gerak aksi sekolah pandemi harus mengkampanyekan masker sebagai upaya melindungi anak anak dan orang orang lain. Jangan sampai droplet yang keluar dari diri anak anak terkena pada orang lain. Jika lebih dari $75 \%$ penduduk patuh menggunakan masker, maka Covid-19 dapat turun secara drastis. akan menekan kasus Covid-19 di Tasikmalaya pada khususnya dan di Indonesia pada umumnya. Hasil penelitian di Amerika, penggunaan masker kain oleh $80 \%$ populasi akan mengurangi 34 - 58\% penambahan kasus kematian (Eikenberry et al, 2020). Hasil penelitian menyatakan bahwa permodelan penggunaan masker oleh minimal populasi tersebut sudah terbukti menekan peningkatan kasus baru dan kematian. Anak-anak tidak suka memakai masker dan kemungkinan besar akan mencobanya untuk melepas bahkan membuangnya, sehingga mereka lebih banyak menyentuh wajah. Mempersiapkan dan mengajarkan anak-anak yang sehat menggunakan masker sangat dibutuhkan untuk mendapatkan kepatuhan yang maksimal (Joko,

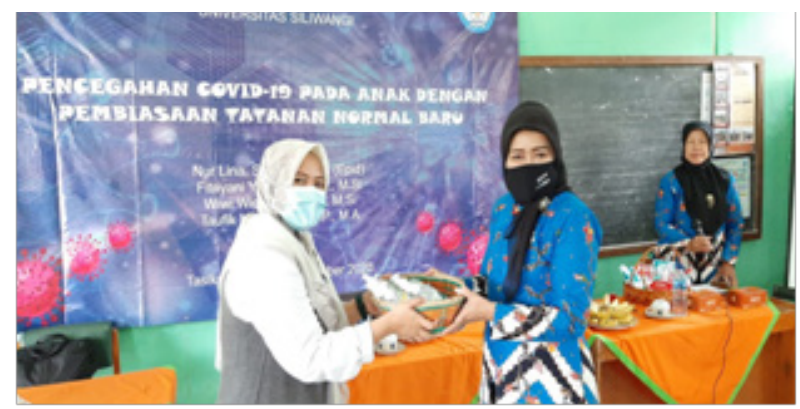

Gambar 6. Penyerahan Hand Sanitizer Secara Simbolis di SDN Cilolohan

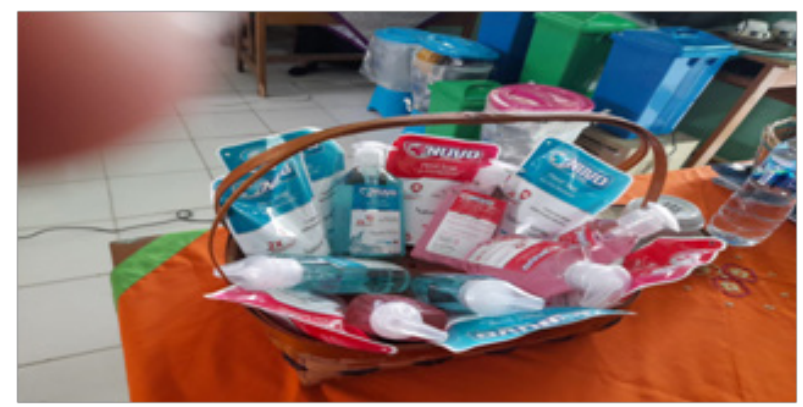

Gambar 8. Penyerahan Sabun Cuci Tangan Secara Simbolis di SDN 1 Cikalang

Warta LPM, Vol. 24, No. 3, Juli 2021 
2020). Mengingat pentingnya penggunaan masker dengan benar untuk pencegahan Covid-19, maka Tim PPM Unsil membagikan masker kepada guru dan anak anak di SDN 1 Cikalang dan SD Cilolohan. Bukti pembagian masker pada gambar 9 dan gambar 10 .

\section{SIMPULAN}

Hasil uji statistik wilcoxon didapatkan $\mathrm{P}$ value 0,007 , artinya terdapat perbedaan nilai rata rata pengetahuan yang signifikan sebelum dan sesudah KIE kepada Guru tentang pencegahan Covid-19 pada anak. Penulis menyarankan agar Guru sebagai kader gerak aksi sekolah pandemi mau melanjutkan kegiatan pengabdian masyarakat Skema Kesehatan (PbM-SK) dengan mengedukasi siswa untuk melakukan upaya pencegahan Covid-19 dengan rajin cuci tangan menggunakan sabun, memakai masker, dan menjaga jarak fisik minimal 1 meter melalui fasilitas cuci tangan, masker, dan media (spanduk, banner) yang diberikan.

\section{PERSANTUNAN}

Penulis mengucapkan terima kasih kepada Lembaga Penelitian dan Pengabdian masyarakat Universitas Siliwangi yang telah memberikan hibah Pengabdian Kepada Masyarakat Skema Kesehatan (PbM-SK), SDN 1 Cikalang, SDN Cilolohan, dan mahasiswa Program Studi Kesehatan Masyarakat dan mahasiswa Program Studi Ilmu Sosial dan Politik Universitas Siliwangi yang terlibat dalam kegiatan ini.

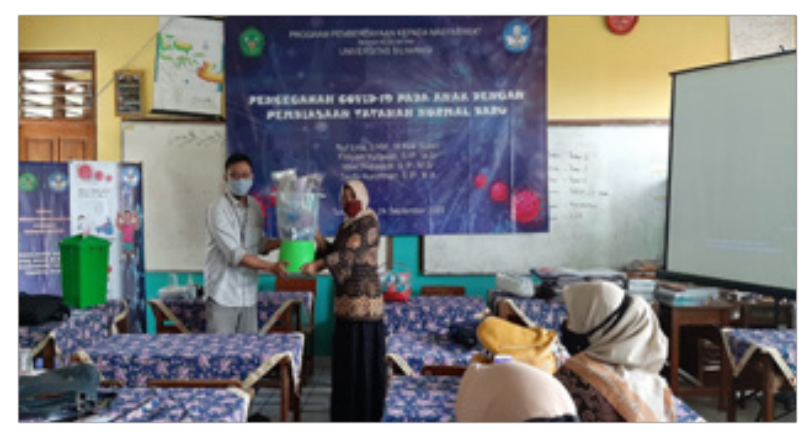

Gambar 9. Penyerahan Masker untuk Guru dan Murid SDN 1 Cikalang

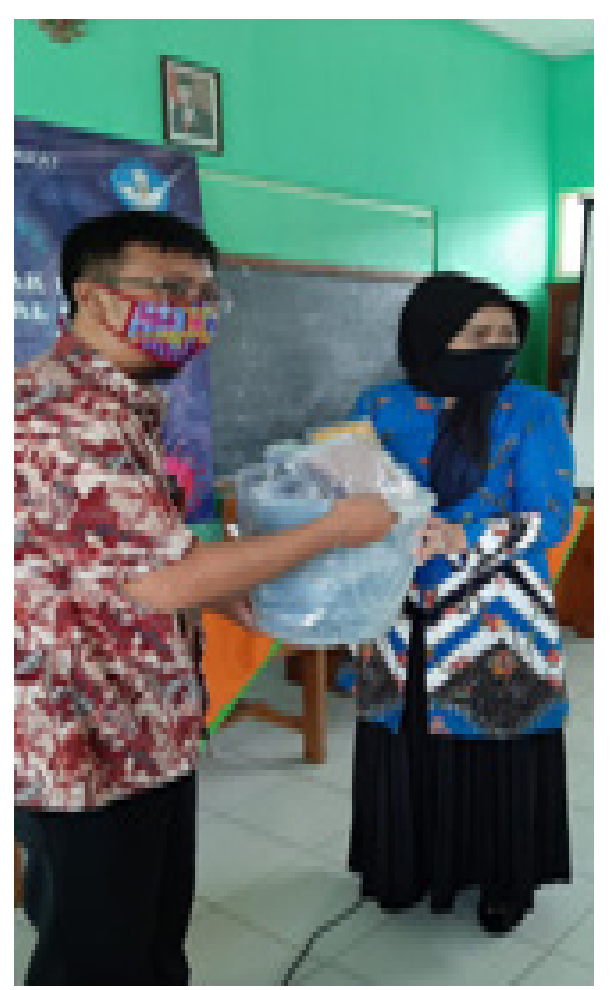

Gambar 10. Penyerahan Masker untuk guru dan Murid SDN 1 Cilolohan

\section{REFERENSI}

Eikenberry. (2020). Modeling the Potential For Face Mask Use by the General Public to Curtail the Covid-19 Pandemic, Infect Dis Model. 2020; 5: 293-308., Published online 2020 Apr 21. doi: 10.1016/j. idm.2020.04.001

H.A. Rothan and S.N. Byrareddy (2020). The Epidemiology and Pathogenesis Of Coronavirus Disease (Covid-19) Outbreak, Journal of Autoimmunity 0896-8411/ (C) 2020 Elsevier Ltd. All rights reserved.

Hidayanti, Lilik., dan Sri Maywati (2019). Program Kemitraan: PMT Penyuluhan Pangan Lokal di Desa Sukarame, Kecamatan Sukarame, Kabupaten Tasikmalaya, Jawa Barat. Warta LPM, 22(1), 38-46

Ikatan Dokter Anak Indonesia, https://www.idai.or.id/tentang-idai/pernyataan-idai/pandanganikatan-dokter-anak-indonesia-mengenai-pencegahan-infeksi-COVID-19-pada-anak 
Joko Tri Atmojo (2020) Avicenna: Penggunaan Masker dalam Pencegahan dan Penanganan Covid-19: Rasionalitas, Efektivitas, dan Isu Terkini. Journal of Health Research, 3(2), 84-94.

Kemdikbud (2020). Pedoman Pelaksanaan Belajar dari Rumah Selama Darurat Bencana Covid-19 Pedoman Pelaksanaan Belajar dari Rumah Selama Darurat Bencana di Indonesia,

Kemenkes (2020). Pedoman Pencegahan dan Pengendalian Coronavirus Disesase (Covid-19) Revisi ke 4, Direktorat Jenderal Pencegahan dan Pengendalian Penyakit (P2P). Kementerian Kesehatan RI.

Kementerian Kesehatan Indonesia. Situasi Terkini Perkembangan Coronavirus Disease (Covid-19) 14 Juni 2020. www.Covid-19.kemkes.go.id. 2020 June

Kementerian Kesehatan RI, https://sehatnegeriku.kemkes.go.id/ diakses 14 Juni 2020.

Marco Cascella1; Michael Rajnik2; Arturo Cuomo3; Scott C. Dulebohn; Raffaela Di Napoli4. (2020) Features, Evaluation, and Treatment Coronavirus (Covid-19). NCBI Bookshelf. A service of the National Library of Medicine, National Institutes of Health. StatPearls [Internet]. Treasure Island (FL): StatPearls Publishing; 2020 Jan

Dinas Komunikasi dan Informatika Kota Tasikmalaya. https://data.tasikmalayakota.go.id/ diakses tanggal 14 Juni 2020

WHO, 2020. Advice on the Use of Masks in the Context of Covid-19, Interim guidance, 5 June 2020

World Health Organization. Novel Coronavirus (2019-nCoV). Available at https://www.who.int/ emergencies/diseases/novel-coronavirus-2019. Accessed June 14, 2020. 